\title{
AKULTURASI BUDAYA EROPA PADA INTERIOR ISTANA MAIMOON MEDAN
}

\author{
Irwansyah \\ Prodi Desain Interior Fakultas Seni dan Desain Universitas Potensi Utama \\ irw.syah23@gmail.com
}

\begin{abstract}
ABSTRAK
Istana Maimoon adalah salah satu dari ikon kota Medan, Sumatera Utara, terletak di kelurahan Sukaraja, kecsmatan Medan Maimoon. Didesain oleh arsitek Italia dan dibangun oleh Sulstan Deli, Makmun Al Rasyid Perkasa Alamsyah pada 1888, Istana Maimoon memiliki luas sebesar $2.772 \mathrm{~m} 2$ dan 30 ruangan. Interior istana maimun merupakan interior yang mewah yang behiasi motif-motif tradisi melayu dengan perpaduan kebudayaan eropa. Akulturasi adalah suatu proses sosial yang timbul manakala suatu kelompok manusia dengan kebudayaan tertentu dihadapkan dengan unsur dari suatu kebudayaan asing. Kebudayaan asing itu lambat laun diterima dan diolah ke dalam kebudayaannya sendiri tanpa menyebabkan hilangnya unsur kebudayaan kelompok itu sendiri. Akulturasi budaya yang timbul karena adanya kontak budaya langsung antara budaya Eropa dengan budaya masyarakat pribumi sehingga menimbulkan kebudayaan baru. Akulturasi terdapat berbagai unsur-unsur yang menyebabkan terjadinya akulturasi, persoalan dan dampak akulturasi serta proses terjadinya akulturasi. Hal-hal tersebut akan diulas sebagai analisis akulturasi.
\end{abstract}

Kata Kunci: Akulturasi, Eropa, Istana Maimoon, Kebudayaan,

\begin{abstract}
Istana Maimoon is one of the icons of Medan city, North Sumatra, located in Kelurahan Sukaraja, the beauty of Medan Maimoon. Designed by Italy and built by Sultan Deli, Makmun Al Rasyid Perkasa Alamsyah in 1888, Issana Maimoon has an area of 2,772 $\mathrm{m} 2$ and 30 rooms. The interior of the palace of Maimun is a luxurious interior that adorns Malay traditional motifs with a blend of European culture. Acculturation is a social process that arises when a group of humans with certain creatures is confronted with not from a foreign culture. Foreign culture is gradually accepted and processed into its own culture without causing cultural imperfection of the group itself. Cultural acculturation arises because of the direct culture between European culture and indigenous culture, giving rise to a new culture. Acculturation is one of the various causes that influence acculturation, interaction and the process of acculturation. These things will be reviewed as an acculturation analysis.
\end{abstract}

Keywords: Acculturation, Culture, Europea, Istana Maimoon 


\section{PENDAHULUAN}

Bangsa eropa datang ke Indonesia sekitar pada abad ke- 14, bangsa eropa awal kedatangannya hanya ingin mencari rempah-rempah dan mencari sutera yang dapat dijual mahal ke eropa. Perdagangan antar negara berkembang pada tahun 1500 masehi yang berubah menjadi hubungan dagang internasional atar Asia Tenggara, Asia Selatan, Asia Timur, Asia Barat dan Eropa. Semenjak dibuka jalur pelayaran yang menghubungkan beberapa Wilayah Asia dengan eropa, aktifitas perdagangan semakin ramai. Berawal dari terjalinnya hubungan perdagangan antar negara tersebut, mulai masuklah pengaruh unsur kebudayaan asing, termasuk yang terutama masuk budaya Eropa ke negara-negara yang ada di wilaya Asia, khususnya juga wilayah Indonesia.

Adanya kegiatan perdagangan tersebut, membuat Indonesia memiliki peranan penting sebagai penyedia barang dagangan seperti tembakau, rempah-rempah, beras, tembaga, emas, timas, kayu dan lain sebagainya. Indonesia juga merupakan berapa pada posisi yang strategis karena ada ditengah jalur pelayaran dan perdagangan dunia. Dan adanya selat malaka yang merupakan pintu masuk untuk perdagangan asing yang masuk ke Indonesia. Pedagang asing masuk ke Indonesia karena penduduk Indonesia sangat padat jadi baik untuk dijadikan tempat pemasaran.

Kerajaan islam menutup jalur perdangan di afrika dan eropa timur membuat perdangan bangsa eropa terganggu. Hal itu membuat bangsa eropa melakukan penjelajahan ke Samudra untuk mencari sumber rempah-rempah dan sutera. Peninggalan dan pengaruh eropa sampai saat ini masih tersisa pada pulau kreta yang dimana pulau greta adalah dasar kebudayaan eropa. Kebudayaan eropa yang ada di pulau kreta di sebarkan oleh bangsa Romawi Kuno dan bangsa Yunani yang dibawa ketika masa penjajahan, sehingga budaya eropa masih terasa sampai saat ini. Hal ini juga terjadi di Indonesia, dimana kebudayaan eropa dibawa melalui adanya hubungan perdagangan yang dilakukan oleh bangsa Prancis, Belanda dan Prancis.

Bangsa eropa penjelajahan Samudra di mulai pada tahun 1511 sampai dengan tahun 1998 dan itulah awal bangsa eropa datang ke Indonesia. Spanyol, Inggris, Portugis dan Belanda adalah bangsa eropa yang masuk atau datang ke Indonesia. Bangsa-bangsa eropa yang datang tersebut memiliki tujuan, yaitu:

a. Untuk melakukan penanaman modal, mencari rempah-rempah dilakukan cara berdagang dengan maksud menambah kekayaan.

b. Untuk menguasai negara-negara yang ada di wilayah benua Afrika dan Asia untuk mendapatkan kejayaan.

c. Untuk melakukan penyebaran agama Nasrani serta melanjutkan perang salib.

Untuk mencapai tujuan-tujuan tersebut, upaya bangsa-bangsa eropa adalah :

a. Menjalankan politik dengan menguasai perdagangan di Indonesia, hal tersebut supaya bangsa-bangsa eropa tersebut bisa menguasai dan mengendalikan ekonomi serta pedagangan di Indonesia.

b. Menguasai wilayah dengan menjalankan politik adu domba.

c. Mengubah kondisi sosial, ekonomi dan budaya di Indonesia sama seperti dengan kondisi yang ada di berbagai negara eropa.

d. Melakukan pembentuka pemerintahan kolonial yang bertujuan untuk bisa mengendalikan kegiatan yang ada di Indonesia. 
Sebagai ibukota Provinsi Sumatera Utara, Kota Medan memiliki sejarah yang panjang. Kota yang berdiri sejak 1590 ini, dulunya merupakan pusat dari pemerintahan Kesultanan Melayu Deli. Istana kesultanan itu sendiri diperkaya dari perpaduan arsitektur khas Melayu, Moghul, Timur Tengah, Spanyol, India, dan Belanda. Dominasi kuning keemasan dan hijau melambangkan kemakmuran sebuah negeri yang kental keislaman. Ketika pertama kali meminjak pintu utama istana Maimoon, akan disuguhkan berbagai keindahan interior yang adanya pengaruh budaya eropah.

\section{I.1. Akulturasi}

Akulturasi adalah suatu proses sosial yang timbul manakala suatu kelompok manusia dengan kebudayaan tertentu dihadapkan dengan unsur dari suatu kebudayaan asing. Kebudayaan asing itu lambat laun diterima dan diolah ke dalam kebudayaannya sendiri tanpa menyebabkan hilangnya unsur kebudayaan kelompok itu sendiri. Contoh akulturasi: Saat budaya rap dari negara asing digabungkan dengan bahasa Jawa, sehingga menge-rap dengan menggunakan bahasa Jawa. Ini terjadi di acara Simfoni Semesta Raya. Menurut Sachari kebudayaan adalah suatu totalitas dari proses dan hasil segala aktivitas suatu bangsa dalam bidang estetis, moral, dan ideasional yang terjadi melalui proses integrasi, baik integrasi historis maupun pengaruh jangka panjangnya.

Koentjaraningrat (1990: 91) mengatakan akulturasi adalah pengaruh kebudayaan asing yang terjadi di suatu masyarakat yang sifatnya berbeda. Kebudayaan asing tersebut terintegrasikan dan diakomodasi ke dalam kebudayaan kita sendiri tanpa kehilangan kebudayaan sendiri.

Ada empat persoalan akulturasi menurut Redfield, yaitu :

1. Pendekatan kepada masalah

Ada beberapa hal bahan-bahan untuk mendapatkan sebuah informasi tentang hal apa saja yang bisa dipengaruhi sehingga terjadinya akulturasi. Ada dua jenis bahan yang diperlukan untuk melakukan pengkajian akulturasi, yaitu:

a. Bahan tertulis

Jenis bahan yang digunakan untuk mendapatkan informasi mengenai sejarah di masa lampu yang merupakan sebuah bukti yang otentik.

b. Bahan tak tertulis

Jenis bahan yang didapatkan secara lisan (cerita). Dengan dua jenis bahan tersebut yang kemudian bisa diklasifikasikan bisa menjadi beberapa bagian tema atau topik pembahasan, yaitu:

$>$ bahan yang menceritakan tentang bentuk keseluruhan atau spesifik budaya

$>$ Bentuk budaya apa yang dibicarakan

$>$ Hal apa saja yang mendorong studi

Bahan yang sudah diklasifikasikan kemudian akan dianalisis dengan cara pengamatan

pada proses akulturasi. Untuk mengkaji akulturasi budaya digunakan studi pustaka atau dokumen, dimana studi pustka diharapkan dapat memberikan pembuktian sejarah awal yang bisa menimbulkan akulturasi. 


\section{Analisis Akulturasi}

Untuk melakukan analisis akulturasi ada beberapa faktor yang menjadi pertimbangan dengan melihat situasi, yaitu:

a. Macam-macam kontak

Kontak budaya yang terjadi pada akulturasi dipengaruhi oleh beberapa situasi, yaitu:

$>$ Berlangsungnya kontak antara seluruh populasi denga populasi lain yang memilih kelompok.

$>$ Berlangsungnya kontak secara ramah atau bermusuhan.

$>$ Berlangsungnya kontak antar kelompok yang seimbang atau memiliki perbedaan yang mencolok.

$>$ Berlangsungnya kontak antar kelompok yang ditandai dengan kerumitan dan derajat yang tidak seimbang di dalam aspek kebudayaan material.

> Hasil kontak dari pembawa kebudayaan datang langsung ke tempat tinggal penerima kebudayaan atau dari kelompok penerima membawa wujud ke dalam kontak dengan kebudayaan baru di wilayah baru.

a. Situasi yang memungkinkan terjadinya akulturasi

Untuk menjelaskan situasi yang muncul yang memungkinkan terjadinya akulturasi, dapat dilihat dari beberapa aspek, yaitu 1) Ketika elemen kebudayaan terdesak oleh orang, atau diterima dengan sukarela oleh mereka, 2) Ketika tidak ada ketidaksetaraan sosial maupun politik antar kelompok, 3) Ketika ketidaksetaraan hidup diantara kelompok, yang pada kasus berikut mungkin menghasilkan dominasi politik oleh salah satu kelompok tanpa pengakuan atas dominasi sosialnya oleh kelompok subjek, dominasi politik dan sosial oleh salah satu kelompok dan pengakuan atas superioritas sosial salah satu kelompok oleh kelompok lain tanpa menggunakan dominasi politik oleh yang lebih dahulu.

\section{Proses Akulturasi}

Proses akulturasi dapat terjadi ketika adanya kontak budaya asing dan budaya lokal, namun budaya tersebut harus memiliki kriteria untuk dapat diterima di dalam kelompok tersebut, yaitu:

a. Pemilihan ciri/sifat dalam akulturasi

b. Penentuan sikap yang diperkenalkan dan dipilih dalam situasi akulturasi

Beberapa sifat yang dipilih dalam proses akulturasi, yaitu

$>$ Sifat yang diperkenalkan oleh kelompok penderma

$>$ Sifat yang dipilih oleh kelompok penerima

$>$ Sifat yang ditolak oleh kelompok penerima.

c. Integrasi/penyatuan sifat ke dalam pola kebudayaan yang diterima

$>$ Faktor waktu yang telah berlalu sejak penerimaan suatu sifat.

$>$ Unsur konflik yang muncul dalam suatu kebudayaan dengan penerimaan sifat baru pada yang berbeda dengan sifat yang telah ada sebelumnya dan derajat konflik yang terjadi.

$>$ Tahap penyesuaian dalam akulturasi

\section{I.2. Istana Maimoon}

Istana Maimun merupakan salah satu dari sekian istana yang paling indah di Indonesia. Bangunan yang didominasi dengan warna kuning keemasan yang identik dengan warna khas 
Melayu, didirikan diatas tanah seluas $2.772 \mathrm{~m} 2$ dan mempunyai 30 ruangan, terdiri dari dua lantai dan memiliki tiga bagian yaitu bangunan induk, bangunan sayap kiri dan bangunan sayap kanan. Istana ini memiliki arsitektur yang unik dengan perpaduan beberapa unsur kebudayaan Melayu bergaya Islam, Spanyol, India dan Italia. Perpaduan ini menyuguhkan keunikan inilah yang memberikan karakter khas bangunannya.

Keunikan perpaduan tradisi Melayu dengan kebudayaan Eropa pada bangunan interiornya yang terlihat dari ornamen lampu, kursi, meja, lemari, jendela serta pintu dorong. Pengaruh Islam dapat dilihat dari bentuk lengkung di beberapa bagian atap istana yang bentuknya menyerupai perahu terbalik yang kerap dikenal dengan sebutan Persia Curve yang biasanya dijumpai pada bangunan-bangunan di kawasan Timur Tengah, India atau Turki. Kemewahan interior dan bangunan fisik istana ini dimungkinkan karena sejak 2 abad silam berada dibawah Kesultanan Deli yang mengelola hasil perkebunan, minyak, dan rempah-rempah yang melimpah. Hasil bumi yang luar biasa tersebut memberikan penghasilan sangat besar kepada Kesultanan Deli dengan bukti kehadiran Istana Maimun yang megah.

Menurut Tengku Moharsyah Nazmi (2016), diruang istana juga di isi dengan ornamenornamen yang menghiasi seluruh bangunan mengambil dari seni Islam yang dapat dilihat seperti pada bagian atas ruangan induk istana yang bercirikan budaya timur tengah. Tidak hanya terdapat pada bagian atas saja tetapi terdapat juga dibagian lain seperti di dinding istana. Kombinasi dari budaya eropa dapat juga terlihat pada interior yang mengisi ruangan induk istana seperti lampu kristal yang berasal dari Prancis serta kipas angin berwarna hitam dari Belanda.

Dapat dilihat juga perpaduan tradisi Melayu dengan kebudayaan Eropa pada bagian pintu yang terletak disisi samping yang menghubungkan antara ruang induk dengan teras dan ruangan disayap Istana. Pintu itu merupakan gabungan antara budaya timur dan budaya barat. Dimana dengan literturnya, bagian atas lebih kepada gaya Mongol dengar pilar atas bergaya Eropa. Uniknya pintu itu tidak seperti pintu-pintu biasanya, pintu istana Maimun, untuk satu pintu ada empat daun pintu. Dalam satu pintu ada dua lembar daun pintu dalam dan ada dua lembar daun pintu luar. Daun pintu luar lebih bergayakan pintu daerah tropis yang memiliki sirip-sirip untuk keluar masuknya sirkulasi udara. Tetapi bentuk pintu tetap menciri khaskan budaya Melayu yang sering terlihat pada rumah-rumah adat Melayu. Pada pintu dalam lebih bergaya Eropa dengan desain kaca bermotif bunga yang untuk menghalangi panasnya matahari yang masuk langsung keruangan. 


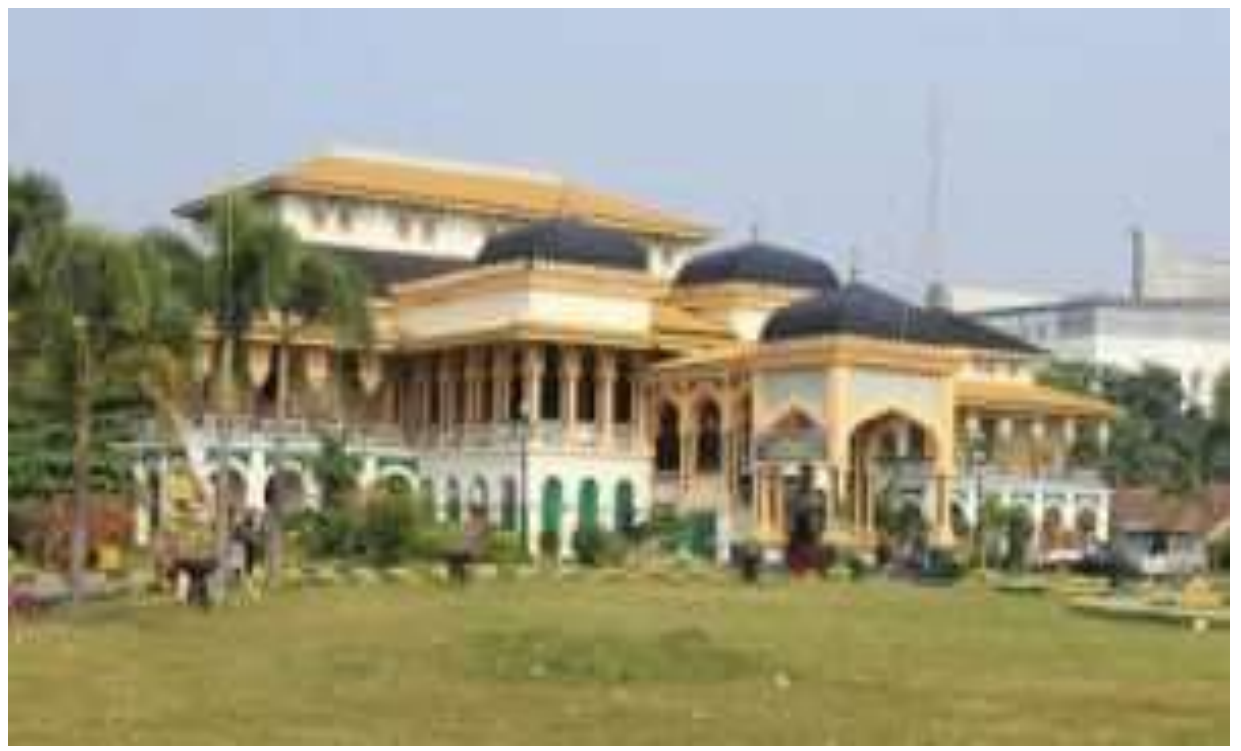

Gambar 1. Istana Maimoon (Kesultanan Deli)

\section{STUDI LITERATUR}

Untuk melakukan penelitian mengenai konservasi pada bangunan bersejarah perlu adanya sebuah rujukan atau acuan penelitian sebelumnya yang diperlukan pada penelitian ini untuk dijadikan perbandingan. Penelitian pertama dari Anik Susanti (2013) dengan judul "Akulturasi Budaya Belanda Dan Jawa (Kajian Historis Pada Kasus Kuliner Sup Dan Bistik Jawa Tahun 1900 - 1942)" didalam penelitiannya, ia mengatakan Masakan sebagai cerminan kondisi sosial masyarakat di Jawa dan masakan sebagai bentuk gaya hidup sosial budaya pada jamannya. Kedua Khoerunisa dengan judul "Akulturasi Budaya Eropa, Hindu Dan Islam Pada Masjid Keraton Kanoman", dimana dalam penelitiannya ia mengatakan Wujud akulturasi budaya Eropa yaitu pada bentuk tiang empat pilar yang tinggi menjulang dan bentuk pintu dan jendela seperti gaya renaissance. Sedangkan akulturasi Hindu terdapat pada atap yang menyerupai meru di Bali serta bentuk persegi bangunan yang seperti pendopo yang berasal dari India.

\section{PEMBAHASAN}

Akulturasi adalah proses sosial yang terjadi apabila kelompok manusia dengan kebudayaan tertentu dihadapkan pada kebudayaan asing yang berbeda, sehingga unsur kebudayaan asing itu lambat laun diterima dan diolah di dalam kebudayaan daerah tanpa menyebabkan hilangnya kepribadian kebudayaan daerah itu sendiri, yang tidak menyebabkan hilangnya kepribadian masing-masing budaya (Koentjaraningrat : 2005).

Kebudayaan lokal yang ada di Kota Medan adalah kebudayaan Melayu. Kebudayaan Melayu mempunyai kekhasan dari segi struktur bangunan dan ornamen. Istana Maimoon salah satu bangunan yang merupakan peninggalan kebudayaan Melayu yaitu Melayu Deli. Istana Maimoon mempunyai kekhasan yang juga menjadi ikon bagi Kota Medan. Istana Maimoon memiliki interior dan eksterior dari perpaduan budaya Eropah dan budaya Melaya (lokal). Budaya lokal yang terlihat pada bangunan Istana Maimoon adalah : 
a. Warna

Pada arsitektur bangunan Istana Maimoon, penggunaan warna pada arsitektur pada bangunan ini terdiri dari tiga warna pokok yaitu kuning, hijau. Dimana Istana Maimun ini juga didominasi dengan warna kuning yang merupakan warna khas Melayu.

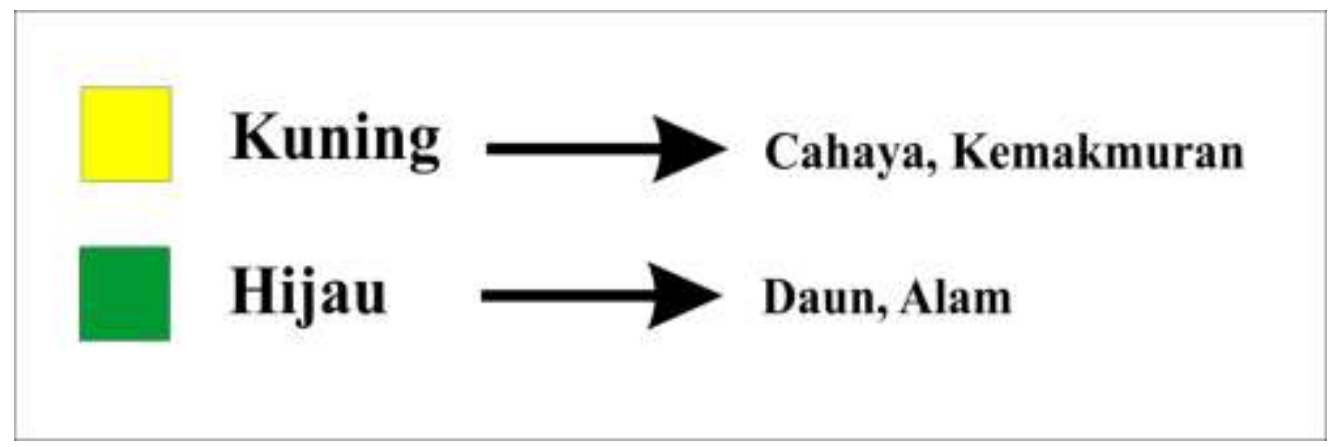

Gambar 2. Warna Pada Istana Maimun Medan

Warna kuning pada istana Maimun ini menyimbolkan kejayaan dan budi pekerti yang luhur, ciri kehidupan kerajaan Melayu. Sedangkan warna hijau biasanya identik dengan agama islam dapat terlihat pada bangunan-bangunan mesjid, dimana warna hijau memiliki makna yang melambangkan kesejukan, merupakan simbol dari alam, keberuntungan, dan sebuah kesehatan. Namun, warna hijau pada istana Maimun memiliki kisah tersendiri. Istana ini juga dikenal dengan nama Istana Putri Hijau karena leganda tentang Putri Hijau yang mewarnai istana kesultanan Deli. Legenda itu bercerita tentang seorang putri bernama Putri Hijau. Ia dijuluki Putri Hijau karena tubuhnya yang memancarikan aura berwarna hijau (Tengku Moharsyah Nazmi : 2016).

b. Jendela dan Pintu

Pintu pada bangunan Melayu selalu terletak dan menghadap ke arah matahari terbit. Jendela pada bangunan Melayu terbuka layar dan selalu memiliki bukaan ke arah luar serta berbentuk sisir dan selalu memanjang ke atas. Budaya Melayu (Lokal) juga dapat dilihat pada Istana Maimoon, dimana pintu yang ada pada Istana Maimoon memiliki dua pasang daun pintu, satu daun pintu pada bagian luar yang merupakan khas bentuk budaya Melayu. Sedangkan bagian dalam pengaruh kebudayaan asing (Eropah). Berikut salah satu bentuk budaya Melayu (Lokal) yang terdapat pada Istana Maimoon. 


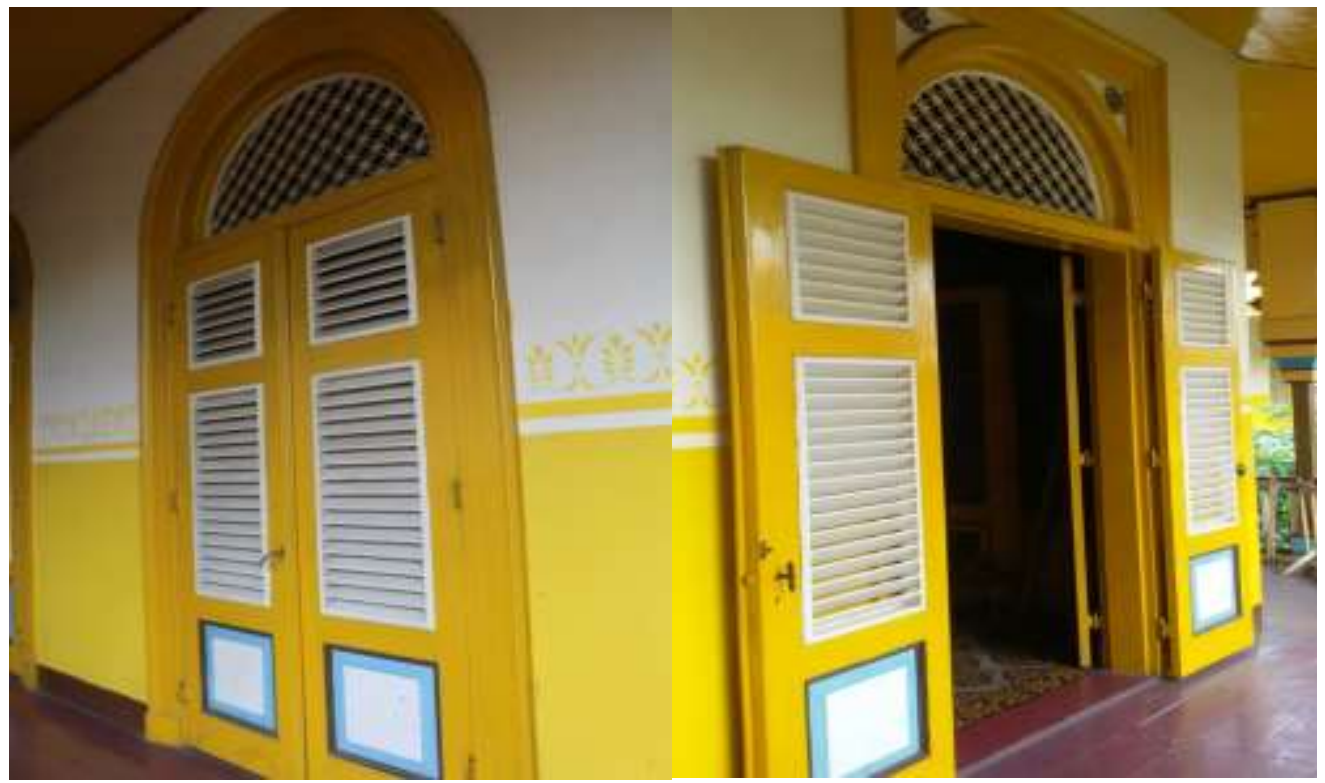

Gambar 3. Pintu Sisi Luar Objek Penelitian

(Sumber: Dokumentasi pribadi peneliti)

Dimana dengan sisi sirip di pintu tersebut untuk ventilasi udara yang dapat menghasilkan sirkulasi udara yang bagus dan dapat menjaga kelembaban dan kehangatan ruangan. Dan pada pintu sisi luar ini juga terdapat handle pintu yang bergaya eropah berbahan baja yang digunakan untuk mengunci pintu.

c. Lantai dan Dinding

Lantai adalah struktur yang horisontal dan memenuhi ruang dalam bangunan. Di dalam istana ini terdapat tiga lantai, yaitu lantai bawah, lantai satu dan lantai dua. Lantai bawah sepenuhnya menggunakan lantai semen termasuk juga dinding dan tiang istana. dan lantai dua pula sebagiannya dari kayu yang telah dikemas dengan kemasan ubin. Lantai kayu yang ada di lantai dua dan lantai tiga adalah di ruang kamar. Kayu yang digunakan adalah jenis kayu keras mudah dikenal sebagai kayu meranti. Dinding bangunan Melayu umumnya terbuat dari papan yang dipasang miring, vertikal, maupun bersilang yang dipenuhi oleh hiasan. Pada dinding ruangan yang ada di Istana Maimoon isi oleh beberapa hiasan dan motif khas budaya Melayu. 


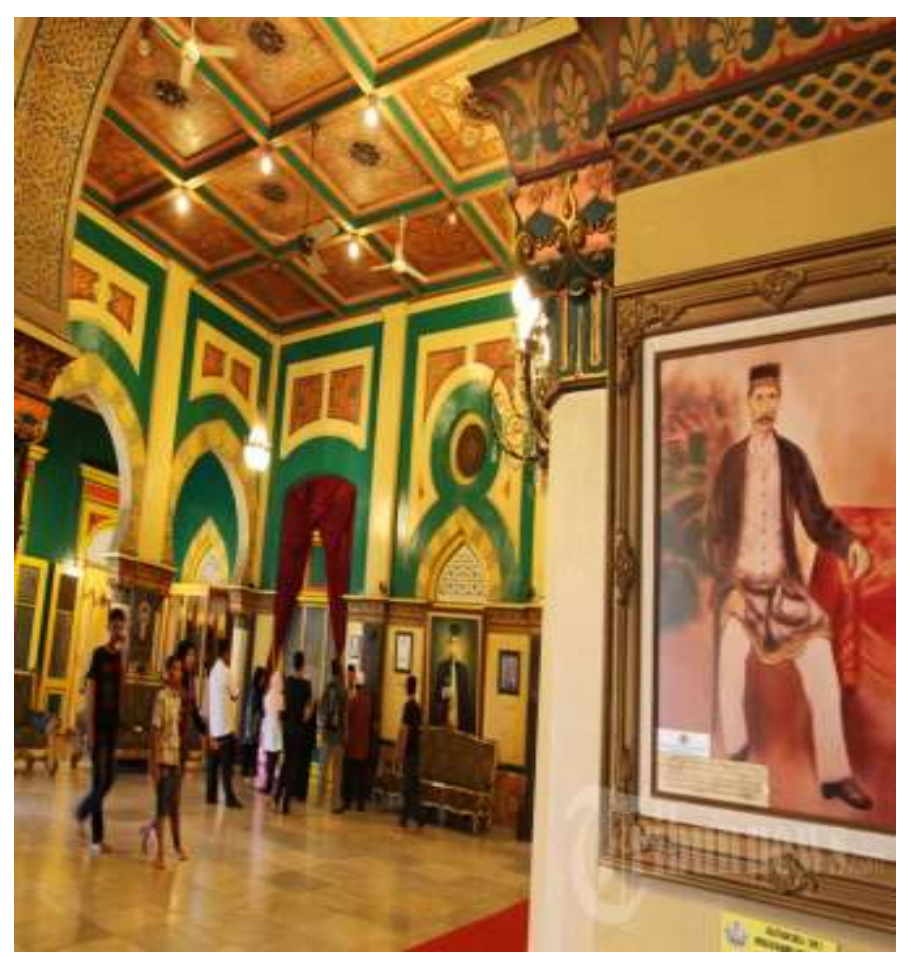

Gambar 4. Dinding Istana Maimun

(Sumber: Internet : 2017)

\section{d. Ornamen/motif}

Ornamen atau motif Melayu banyak ditemukan pada bangunan Melayu, tidak luput pula pada interior dan eksterior Istana Maimoon banyak terdapat ornamen/motif melayu tersebut.

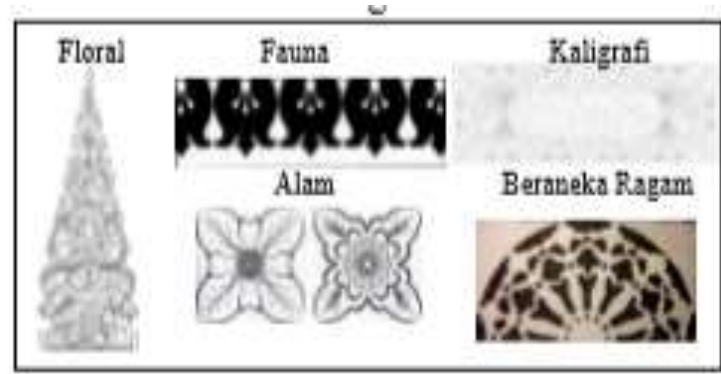

Gambar 5. Ornamen Arsitektur Melayu

(Sumber : Ayu Kartini, 2014)

\section{Akulturasi Budaya Eropah Pada Istana Maimoon}

Elemen kebudayaan Eropah diambil dan dibawa kedalam kebudayaan lokal. Namun, dalam mengadopsi budaya asing tersebut, masyarakat pribumi memilih budaya yang sifatnya sesuai dengan kebudayaan lokal. Hal ini, menunjukan bahwa masyarakat pribumi memiliki kebudayaan yang tinggi (local jenius).

Pembahasan dalam penelitian ini adalah membahas mengenai Kerajaan Deli yang terpengaruh oleh budaya eropa, salah satu pengaruh yang bisa kita lihat adalah dibagian Istana Maimoon. Dimana arsitektur bangunan Istana Maimoon dipengaruhi oleh beberapa unsur kebudayaan Eropa, 
salah satu diantaranya adalah Italia. Eropa masuk ke wilayah Sumatera bagian timur melalui perdagangan tembakau. Wilayah kesultan deli kaya dengan hasil tembakaunya.

Lampu-lampu kristal yang menerangi singgasana sebagai bukti adanya pengaruh budaya Eropa. Pengaruh itu juga tampak pada perabotan istana seperti kursi, meja toilet, dan lemari hingga pintu dorong menuju balairung.

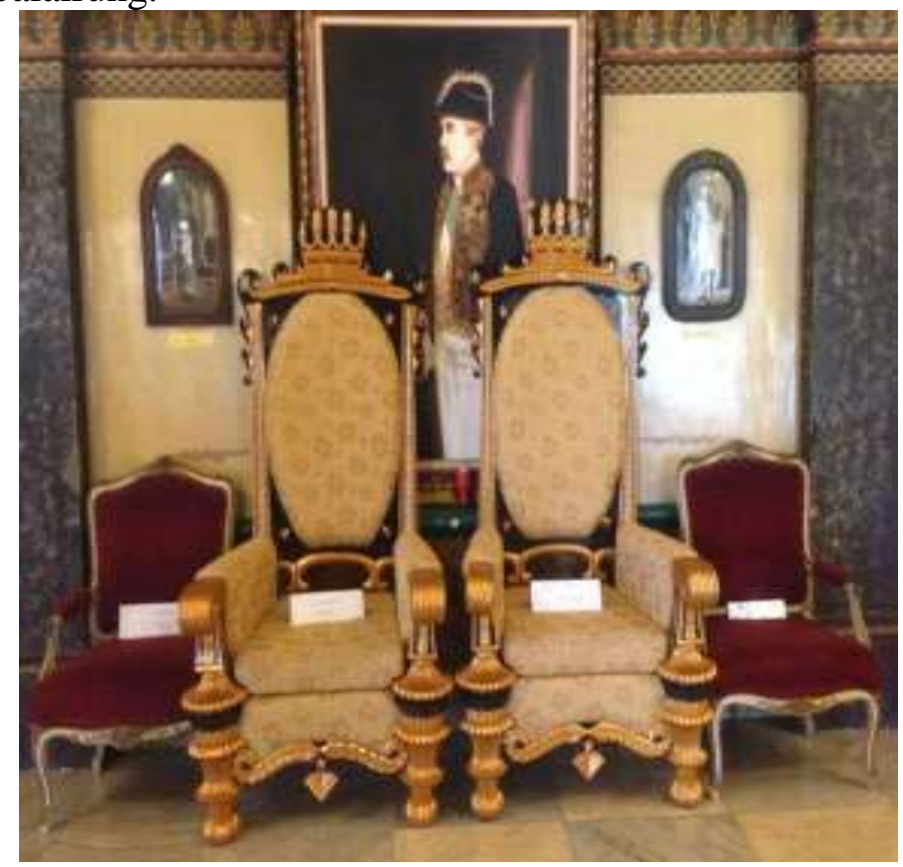

Gambar 6. Kursi Tahta Sultan Berada di Ruang Balairung (Sumber: Dokumentasi pribadi peneliti)

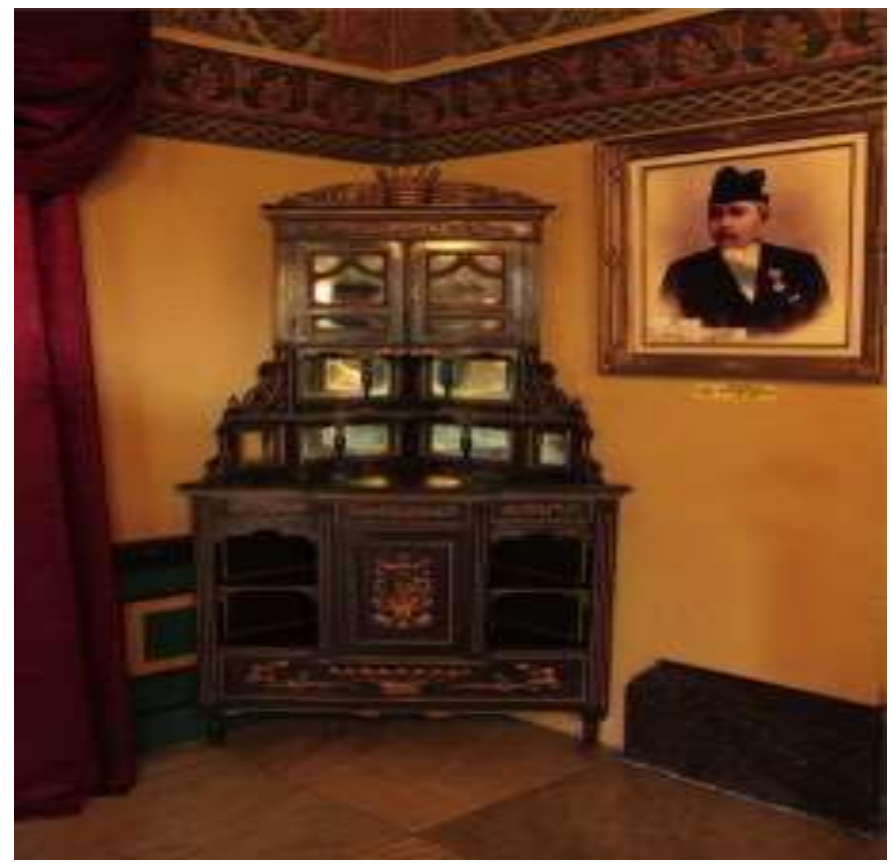

Gambar 7. Lemari Yang Melengkapi Interior Ruang Induk Istana Maimun (Sumber: Dokumentasi pribadi peneliti) 
Belum termasuk 4 kamar mandi, gudang, dapur, dan ruang penjara di lantai bawah. Arsitekturnya perpaduan antara tradisi Islam dan kebudayaan Eropa. Sebagian material bangunannya konon juga didatangkan dari Eropa, seperti ubin, marmer, dan teraso.

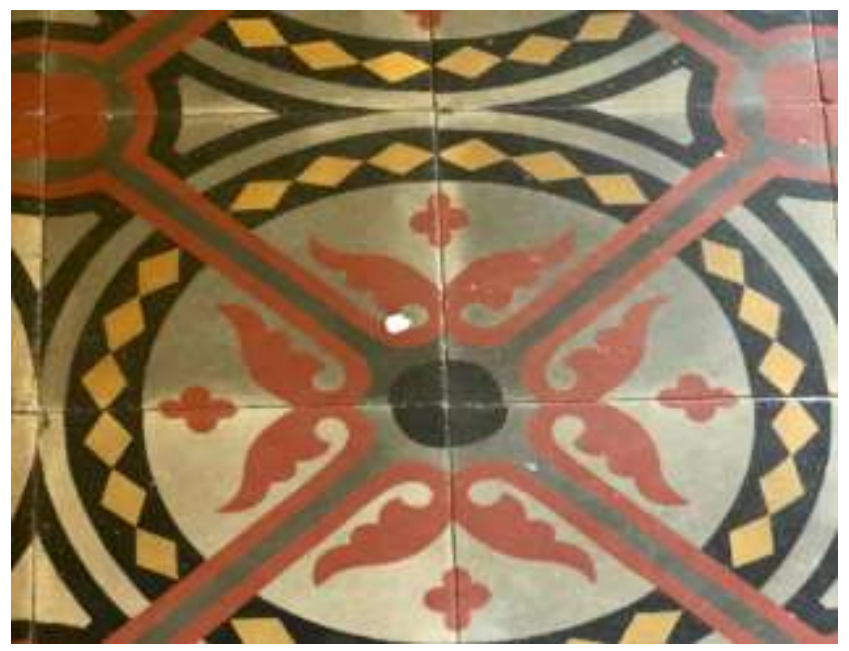

Gambar 8. Ubin di Istana Maimoon

(Sumber: Dokumentasi pribadi peneliti)

Pintu pada istana Maimun terdapat motif sisir pada bagian dua daun pintu luar yang umumnya terdapat pada pintu rumah-rumah khas melayu yang memiliki fungsi atau makna tersendiri. Sedangkan pada bagian daun pintu dalam juga memiliki nilai estetika dengan bentuk bergaya eropa dimana terdapat kaca yang memiliki perpaduan motif bunga, bunga khas melayu (bunga matahari) dan bunga-bunga lainnya seperti bunga cengkeh. Pada pintu istana Maimun terdapat bentuk yang berbeda dengan bentuk pintu-pintu yang ada, dimana bentuk memiliki bentuk persegi, rata dengan dinding karena memiliki material yang sama dengan dinding. Dan pada bagian atas pintu berbentuk seperti kurva atau kapal terbalik yang bergaya timur tengah.

Perpaduan tradisi Melayu dengan kebudayaan Asia dapat dilihat pada bagian pintu yang terletak disisi samping yang menghubungkan antara ruang induk dengan teras dan ruangan disayap Istana. Dimana dengan literturnya, bagian atas lebih kepada gaya Mongol dengar pilar atas bergaya Asia. Uniknya pintu itu tidak seperti pintu-pintu biasanya, pintu istana Maimun, untuk satu pintu ada empat daun pintu. Dalam satu pintu ada dua lembar daun pintu dalam dan ada dua lembar daun pintu luar. Daun pintu luar lebih bergayakan pintu daerah tropis yang memiliki sirip-sirip untuk keluar masuknya sirkulasi udara. Tetapi bentuk pintu tetap menciri khaskan budaya Melayu yang sering terlihat pada rumah-rumah adat Melayu. Pada pintu dalam lebih bergaya Eropa dengan desain kaca bermotif bunga yang untuk menghalangi panasnya matahari yang masuk langsung keruangan. 


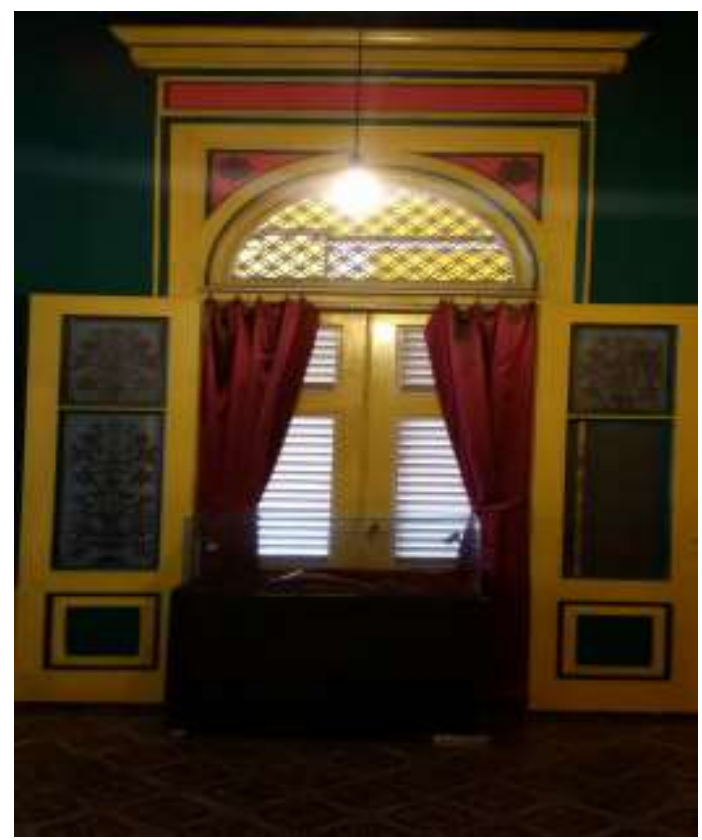

Gambar 9. Pintu Istana Maimun dari Sisi Bagian Dalam Dan Sisi Bagian Luar (Sumber: Dokumentasi pribadi peneliti)

Pengaruh budaya eropa juga terlihat pada langit-langit Istana Maimoon dan juga lampu krital yang tergantung ruangan Utama Istana Maimoon. Di atas singgasana sultan itu terdapat lampu kristal bergaya Eropa yg menerangi singgasana. Singgasana ini masihlah dipakai sampai sekarang pada waktu seremoni-seremoni tertentu, contohnya pengangkatan sulatan atau diwaktu sultan menerima sembah sujud dari para anggota keluarga di perayaan hari-hari Raya Islam.

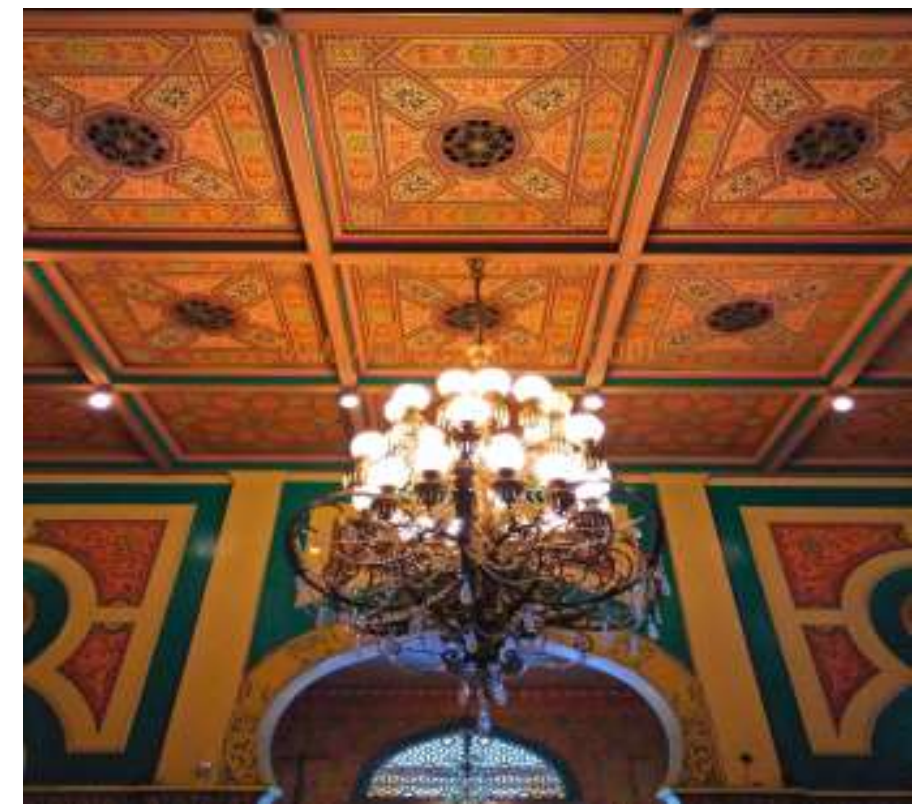

Gambar 10. Langit-langit dan lampu krista di ruangan Utama Istana Maimoon (Sumber: Dokumentasi pribadi peneliti) 
Nuansa Melayu tampil pada desain pintu, desain gerigi di balkon dan lorong, serta warna kuning emas yang digunakan warna yang identik dengan budaya Melayu. Sementara kreasi langgam Mughal dan Timur Tengah bisa dilihat pada desain lengkung yang hadir di setiap sisi istana, ornamen dekoratif pada plafon, dan desain kubah. Ruangan tampil megah dengan chandelier keemasan yang tergantung mewah di langit-langit.

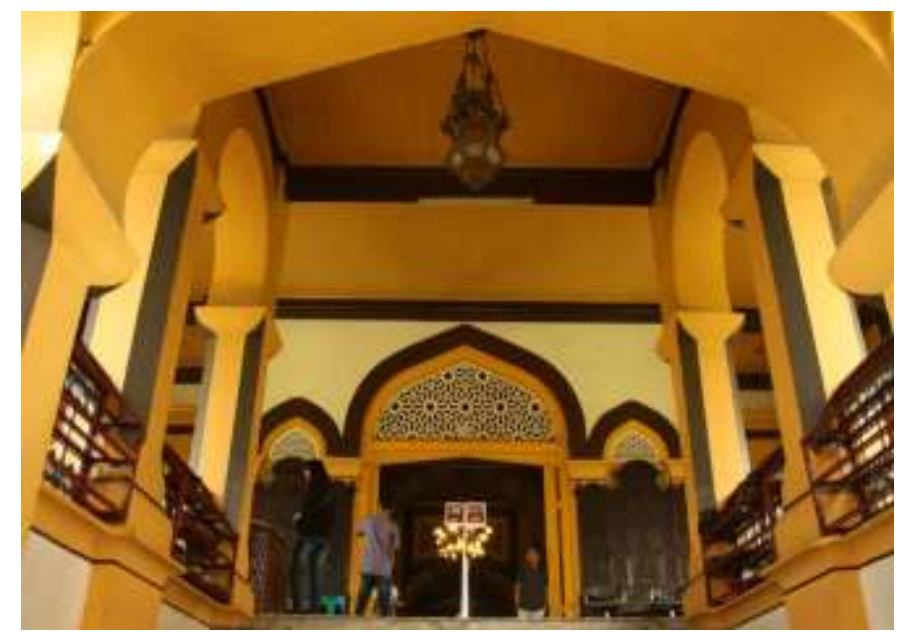

Gambar 11. Pintu utama ketika Memasuki Bangunan Utama Istana Maimun (Sumber: Dokumentasi pribadi peneliti)

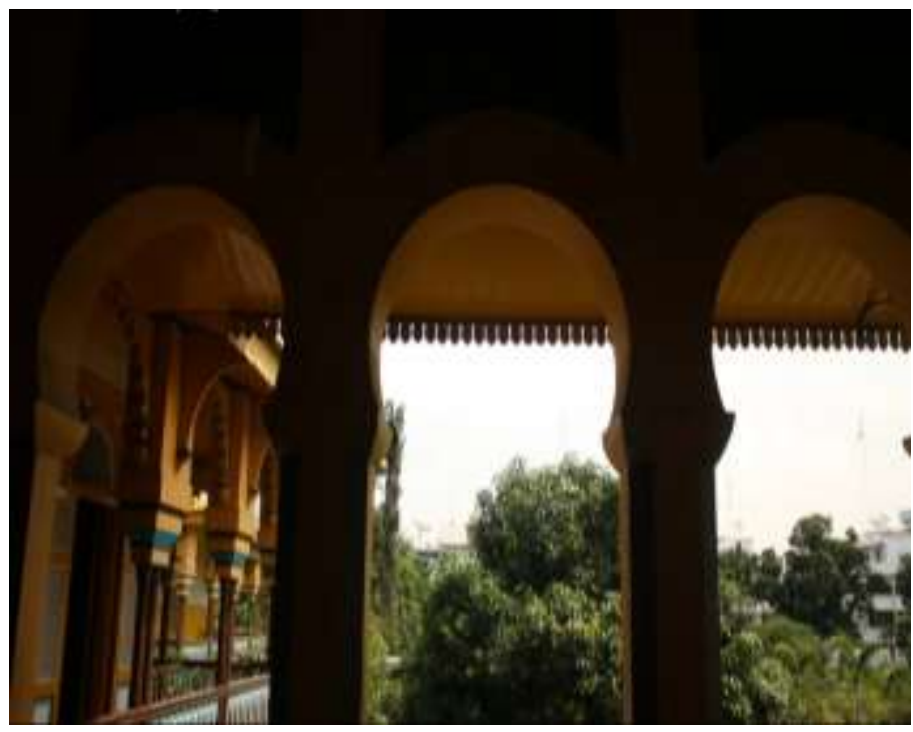

Gambar 12. Desain gerigi di balkon dan Lorong (Sumber: Dokumentasi pribadi peneliti) 


\section{KESIMPULAN}

Bangsa Eropa yang hadir di Indonesia pada akhir abad ke-6 semula bertujuan untuk berdagang. Namun, demi mengamankan sektor ekonomi dan perdagangannya, tujuan mereka berubah menjadi penguasa berdaulat. Dalam proses akulturasi kedua kebudayaan tersebut, penguasa eropa lebih dominan dibanding dengan bangsa Indonesia yang terjajah, sehingga bangsa Indonesia harus menerima dan menyesuaikan dengan aparat penguasa jajahan.

Keunikan perpaduan tradisi Melayu dengan kebudayaan Eropa pada bangunan interiornya yang terlihat dari ornamen lampu, kursi, meja, lemari, jendela serta pintu dorong. Pengaruh islam dapat di lihat dari bentuk lengkungan di beberapa bagian atap istana yang bentuknya menyerupai perahu terbalik yang kerap dikenal dengan sebutan Persia Curve yang biasanya banyak dijumpai pada bangunan-bangunan dikawasan Timur Tengah, India atau Turki.

Akulturasi muncul karena adanya kontak budaya antara budaya setempat dengan budaya asing sehingga menghasilkan budaya baru tanpa menghilangkan identitas budaya lokal. Namun proses akulturasi dalam masyarakat tidak selalu berjalan lancar, seimbang dan memberikan manfaat yang positif. Disisi lain pasti selalu ada kelompok yang sukar sekali atau bahkan tidak dapat menyesuaikan diri dengan perubahan-perubahan yang terjadi. Perubahan-perubahan dalam golongan masyarakat tersebut dianggap sebagai keadaan krisis yang membahayakan keutuhan masyarakat. Kebudayaan eropa yang masuk ke dalam wilayah Kesultanan Deli hanya di rasakan pada Arsitektur bangunan Istana Maimoon.

Akulturasi budaya yang timbul karena adanya kontak budaya langsung antara budaya Eropa dengan budaya masyarakat pribumi sehingga menimbulkan kebudayaan baru. Sedangkan dalam akulturasi terdapat berbagai unsur-unsur yang menyebabkan terjadinya akulturasi, persoalan dan dampak akulturasi serta proses terjadinya akulturasi. Hal-hal tersebut akan diulas sebagai analisis akulturasi.

\section{DAFTAR PUSTAKA}

[1] Ching, Francis D.K, and Corky, Bingeli. 2011. Interior Desain dengan Ilustrasi, Edisi kedua, Terjemahan. Jakarta: Indeks.

[2] Francis B. Affandi. 2011. Bangunan Bersejarah

[3] Koentjaraningrat. 1990. Manusia dan Kebudayaan Indonesia. Jakarta : Djambatan.

[4] Mahnke, Frank.H. 1996. Color, Environment \& Human Response. John Wiley \& Sons, Inc.

[5] Meleong, L.J., 1991, "Metodologi Penelitian Kualitatif”, 3, 50, PT Remaja Rosdakarya, Bandung.

[6] Nazmi, T. Moharsyah. 2016. Sejarah Istana Maimun Medan, Medan. 
[7] Susanti, Anik. 2013. AKULTURASI BUDAYA BELANDA DAN JAWA (Kajian Historis pada Kasus Kuliner Sup dan Bistik Jawa Tahun 1900 - 1942). Universitas Negeri Surabaya.

[8] Wiyancoko, Dudy. 2007. Desain dan Perkembangan Teknologi di Indonesia. Jakarta 